\title{
Business Orientation among Poor Dry Zone Farmers in Sri Lanka
}

\author{
Dilini Hemachandra and Sarath S. Kodithuwakku*
}

\begin{abstract}
Commercialization of agricultural sector through diversification into high value agriculture has been identified as a viable strategy for up-scaling the socio-economic status of poor rural farmers, the success of which is largely dependant upon their degree of market orientation. This study attempted to investigate business orientation of poor farmers in terms of the extent to which they are market as opposed to production oriented, which was also dependant upon their degree of commercial orientation. The study was conducted among 897 poor dry zone farmers. The study first investigated into the commercial versus subsistence orientation of the farmers. The routine decision criteria adopted by farmers that were devoid of market considerations were considered as production orientated whereas the corresponding decisions that deviated from routine production orientation towards greater integration of market considerations were considered as market orientated. A score were assigned from a scale varying from 1 to 6 for both orientations representing the number of production/marketing criteria considered by each farmer in production related decision making. Findings revealed that the overall business orientation of the farmers culminated in production orientation with a little deviation towards market orientation in the case of Other Field Crops (OFCs), which was mainly grown for commercial purposes as opposed to paddy and vegetables that were mainly grown for fulfilling subsistence requirements. This brings about the need for placing a greater emphasis on inculcating market oriented mind sets among farmers for making rural socio-economic development a reality.
\end{abstract}

* The authors are, respectively, student and Senior Lecturer in the Department of Agricultural Economics and Business Management, University of Peradeniya. 


\section{Introduction}

It is an undeniable fact that the majority of dry zone paddy farmers are characterized by poor economic status. Production oriented decision making that is not economically viable has been identified as a prominent reason for the socio-economic failure of these farmers (Kodithuwakku and Rosa, 2002). Hence, commercialization of farming through encouraging them to diversify from paddy to high value agriculture has been identified as a viable strategy for up-scaling their socio-economic status, the success of which is largely dependant upon the degree to which they are market oriented (Silva et al., 1999). Despite various initiatives taken by the government and Non-Government Organizations (NGOs) to develop knowledge, skills as well as related infrastructure, the desired outcomes are yet to be realized. This study was undertaken with the objective of assessing the market orientation of farmers who have been identified by a leading INGO of the country as beneficiaries in its development interventions that are aimed also at improving agricultural commercial orientation of farmers.

\section{Literature Review}

The rural farming context of Sri Lanka is characterized by limited and fragmented land, seasonal labor, inadequate capital and prevailing highly imperfect agricultural market systems leading to a highly constrained business environment (Kodithuwakku and Rosa, 2002). A significant portion of the rural population of the country lives below poverty line (Census and Statistics, 2006/07). A number of authors have argued that survival and the subsequent success of the farmer is determined by his/her ability to adapt to changing conditions in the surrounding environment (Johnston and Bryant, 1987; Bryant, 1989; Janssens and Krikke, 1990), which may involve a management process representing choices that are made in terms of combinations of factors of production to recognize the changes involved in relative input costs or modification of the mix of products or services that are already being offered (Bryant, 1989). Internal and external economic considerations of the farm play a major part in managing it as the farmers have to make various choices between alternative uses of resources in the attempt to satisfy the needs and objectives of all concerned (Giles, 1990). The farmer in such a context should play the role of a manager in terms of

considering the resources available to the farm and the technical possibilities 
for combining them, the opportunities offered, and the constraints imposed by the environment (King and Sonka, 1985).

Greater majority of rural farmers belong to the category of Limited Resource Farmers (LRF). The LRFs usually act as "price-takers" (Meulenberg, 1986; Wossink, 1990) and hence are incapable of influencing prices they receive for their produce (Cornelius, 1988; Giles, 1990). This tendency by the LRF can be taken as a perspective reinforced by the fragmented nature of agricultural production, with many individuals producing similar produce. Their scale of production, on the other hand, can never influence the farm gate price (Ferris, 1988). The price-taking nature of the LRF strictly limits the room for maneuver their marketing activities (Giles, 1990). This condition has further been aggravated as LRFs have limited capacities for managing the market mix because they have scarce contacts with the final consumer (Meulenberg, 1986).

As an individual farmer is not usually capable of developing markets for his produce the profits may only be improved through working within the framework of existing markets (Carkner, 1989). This necessitates farmers to be more market oriented in their attempt to survive and prosper (Cornelius, 1988; Brunaker, 1990) which could be achieved through adopting marketing strategies in order to (a) exploit the full potential income that existing markets offer (Cornelius, 1988; Dagher and Christy, 1991) and to (b) manage the risks the surrounding environment presents (Cornelius, 1988). These strategies may be identified as choices made in terms of (a) the market level at which the farm decides to compete and (b) the tactical dimensions such as product (what to supply and of what quality - e.g. varieties of crops, breeds of animals etc. (Ferris, 1988), price (at what cost), distribution (where, when, what services), and promotion (what information) (Dagher and Christy, 1991).

It has been observed that the majority of rural farmers tend to follow well-established routine traditional decision paths (Bryant, 1989). These routines have been established mainly as a result of the increased openness of the agricultural production environment (Bryant, 1989) and have been identified as being "production-orientated" (Brunaker, 1990; Dagher and Christy, 1991). They allocate more time, energy, and resources for production than to marketing (Dagher and Christy, 1991) and, the eventual result is lowincome leading to socio-economic failure. Hence, individual farmers are being forced to face the interdependence of production and marketing 
decisions such as what to produce, of what quality, when to produce, at what times and in what markets the produce should be sold (Cornelius, 1988; Giles, 1990), which eventually leads to the need for farmers to adopt integrated production and marketing strategies which have to be implemented well before the commencement of production (Cornelius, 1988) for them to be regarded as market oriented. Such market oriented decisions criteria are summarized in the Table 1.

Table 1: Strategies Adopted by LRFs in Order to Adapt to the (Market) Environment

\begin{tabular}{|c|c|c|}
\hline $\begin{array}{l}\text { Strategic Action } \\
\text { (Decision Criteria) }\end{array}$ & Logic for the Action & References \\
\hline What to produce? & $\begin{array}{l}\text { (a)given the soil, climate and the presence of } \\
\text { absence of a certain crop, selecting the best } \\
\text { combination of products to gain advantage } \\
\text { (b)focusing a specific niche market (or } \\
\text { excluding other markets) to gain a higher } \\
\text { margin/reduce risk through crop } \\
\text { diversification } \\
\text { (c)to differentiate the product from traditional } \\
\text { ones on price/introducing new crop or product } \\
\text { to an area to gain advantage over others } \\
\text { (d)gain a comparative/competitive advantage } \\
\text { by selecting a particular commodity of } \\
\text { combination of commodities to suit a farmer's } \\
\text { resource status } \\
\text { (e)produce what can be sold rather than hope } \\
\text { to sell what cannot be produced (subject to } \\
\text { internal and external environmental } \\
\text { conditions) }\end{array}$ & $\begin{array}{l}\text { (a) Carkner (1989) } \\
\text { (b)White (1989) } \\
\text { (c)Barkley and } \\
\text { Wilson (1992) } \\
\text { (d)Ikerd (1989) } \\
\text { (e)Giles (1990) }\end{array}$ \\
\hline $\begin{array}{l}\text { How should I best } \\
\text { produce them? }\end{array}$ & $\begin{array}{l}\text { (a)adapting a new technology (innovation) to } \\
\text { gain cost advantage } \\
\text { (b)become more efficient by decreasing the } \\
\text { input use to increase profit and thus to gain } \\
\text { competitive advantage over others } \\
\text { (c)relatively efficient use of resources in } \\
\text { production to gain comparative advantage } \\
\text { over others and become competitive by } \\
\text { providing products to the market at a lower } \\
\text { cost }\end{array}$ & $\begin{array}{l}\text { (a)Barkley and } \\
\text { Wilson (1992) } \\
\text { (b)White (1989) } \\
\text { (c)Ikerd (1989) }\end{array}$ \\
\hline $\begin{array}{l}\text { How much to produce? } \\
\text { (it has been argued that } \\
\text { increased capacity of } \\
\text { earning and } \\
\text { accumulation of capital } \\
\text { are dependant on steady }\end{array}$ & $\begin{array}{l}\text { (a)to reduce the cost of production in order to } \\
\text { gain a higher margin (this determine where to } \\
\text { sell the products) } \\
\text { (b)farm more units or expand the enterprise to } \\
\text { gain more and complete use of existing } \\
\text { unused resources/ spread fixed cost over more }\end{array}$ & $\begin{array}{l}\text { (a)Ferris (1988) } \\
\text { (c)White (1989) }\end{array}$ \\
\hline
\end{tabular}


35

\begin{tabular}{|c|c|c|}
\hline $\begin{array}{c}\text { Strategic Action } \\
\text { (Decision Criteria) }\end{array}$ & Logic for the Action & References \\
\hline $\begin{array}{l}\text { expansion of the size of } \\
\text { farm operation (Heron } \\
\text { et al., 1994) }\end{array}$ & units of output (economies of scale) & \\
\hline When to produce? & $\begin{array}{l}\text { (a)to take the advantage of market windows } \\
\text { caused by seasonality in production due to } \\
\text { variability in climatic conditions, physiology } \\
\text { of crops and cultural practices. }\end{array}$ & $\begin{array}{l}\text { (a)Colette and } \\
\text { Wall (1978) }\end{array}$ \\
\hline Of what quality? & $\begin{array}{l}\text { (a)target niche markets to increase net margin } \\
\text { (b)to differentiate the product to gain price } \\
\text { advantage } \\
\text { (c)to gain a price advantage (this determine } \\
\text { where to sell too) } \\
\text { (d)to gain competitive advantage by exploiting } \\
\text { quality differences (i.e. to obtain price } \\
\text { premium for quality) } \\
\text { (e) to exploit the quality differences to gain a } \\
\text { higher margin }\end{array}$ & $\begin{array}{l}\text { (a)Dagher and } \\
\text { Christy (1991) } \\
\text { (b)Barkley and } \\
\text { Wilson (1992) } \\
\text { (c)Ferris (1988) } \\
\text { (d)White (1989) } \\
\text { (e)Giles (1990) }\end{array}$ \\
\hline When to sell? & $\begin{array}{l}\text { (a)store and sell grains to reduce market risk } \\
\text { (b)to take the advantage of variability in } \\
\text { market prices caused by changing } \\
\text { environmental factors } \\
\text { (c)perishable nature of agricultural produce } \\
\text { (d)to gain the price advantage by focusing } \\
\text { specific market windows }{ }^{3} \\
\text { (e)to maximize the average returns by timing } \\
\text { the sales (this is aimed at minimizing the risk } \\
\text { created due to the volatility of the market) } \\
\text { (f)store and sell at a higher price to gain a } \\
\text { higher profit } \\
\text { (g)examine the price changes to determine } \\
\text { when early marketing or delay is the more } \\
\text { profitable alternative } \\
\text { (h)to exploit price variations in order to get a } \\
\text { higher price }\end{array}$ & $\begin{array}{l}\text { (a)Nelson (1989) } \\
\text { (b)Smidts (1990) } \\
\text { (c)Dagher and } \\
\text { Christy (1991) } \\
\text { (d)Barkley and } \\
\text { Wilson (1992) } \\
\text { (e)Ferris (1988) } \\
\text { (f)White (1989) } \\
\text { (g)Gutierrez and } \\
\text { Dalsted, 1989) } \\
\text { (h) Giles (1990) }\end{array}$ \\
\hline Who/where to sell? & $\begin{array}{l}\text { (a)focusing a specific niche market (or } \\
\text { exclude other markets)or distribution channel } \\
\text { to gain a higher margin/identify new } \\
\text { markets/reduce market risk through hedging }\end{array}$ & $\begin{array}{l}\text { (a)White (1989) } \\
\text { (b) Smidts (1990) } \\
\text { (c)Ferris (1988) } \\
\text { (d)Giles (1990) }\end{array}$ \\
\hline
\end{tabular}

${ }^{3}$ A particular period of time during which there exists a favourable probability that a commodity can be marketed at a profit. This period will exist when supply from traditional sources is relatively low or during periods of unusually high demand (Barkley and Wilson, 1992) 
36

\begin{tabular}{|c|c|c|}
\hline $\begin{array}{l}\text { Strategic Action } \\
\text { (Decision Criteria) }\end{array}$ & Logic for the Action & References \\
\hline & $\begin{array}{l}\text { (b)choice of a marketing channel by farmers in } \\
\text { order take a higher price (geographical market } \\
\text { windows) } \\
\text { (c) to gain a price advantage by selling a } \\
\text { product of different quality } \\
\text { (d)to exploit the price differences in different } \\
\text { marketing alternatives }\end{array}$ & \\
\hline In what form to sell? & $\begin{array}{l}\text { (a)expansion of industrial uses of agricultural } \\
\text { produce or value enhancement activities using } \\
\text { agricultural produce to gain a higher margin }\end{array}$ & $\begin{array}{l}\text { (a)Barkley and } \\
\text { Wilson (1992) }\end{array}$ \\
\hline How to sell? & $\begin{array}{l}\text { (a)e.g. access the market quickly due to the } \\
\text { perishable nature of agricultural produce (e.g.- } \\
\text { pooling arrangements, contract production, co- } \\
\text { operative marketing, direct selling to final } \\
\text { consumer) } \\
\text { (b)focusing a specific niche market (or } \\
\text { exclude other market) to gain a higher margin/ } \\
\text { vertical integration-obtain more profits by } \\
\text { moving higher or lower into the marketing and } \\
\text { distribution channels (e.g. direct marketing }{ }^{4} \text { ). } \\
\text { (c)focusing a unique niche market (by its } \\
\text { location, income class, age, race or buying } \\
\text { habits) to gain price advantage } \\
\text { (d)cash sales, forward contracting to reduce } \\
\text { risk } \\
\text { (e)how much marketing functions should } \\
\text { farmer perform in order to gain a higher price } \\
\text { (f)how much to sell in each selling option }\end{array}$ & $\begin{array}{l}\text { (a)Dagher and } \\
\text { Christy (1991) } \\
\text { (b)White (1989) } \\
\text { (c)Barkley and } \\
\text { Wilson (1992) } \\
\text { (d)Nelson (1989) } \\
\text { (e)Ferris (1988) } \\
\text { (f)Smidts (1990) }\end{array}$ \\
\hline
\end{tabular}

Source: Kodithuwakku, 1997

\section{Methodology}

\section{Population and the Sample}

Two populations of farmers were identified as beneficiaries and non-beneficiaries based on a development intervention by an INGO in Anuradhapura and Hambanthota Districts. A random sample of 450 farmers was drawn from each population above. There were three nonrespondents from both samples.

${ }^{4}$ Selling to the final consumer. 


\section{Data Collection}

A questionnaire survey was carried out in collecting data. The questionnaire comprised of questions identified based on reviewed literature, for eliciting potential production and marketing decision criteria adopted by the farmers in relation to crop production activities. The decision criteria were the selection of crops to be grown (what to produce?), the quality to be achieved (Of what quality?), the amount to be produced (how much?), the way they are to be produced (How should I best produce them?), the timing of cultivation (when to produce?) the choice of market (where to sell?), the method of selling (how to sell?) and the form of selling (See Table 1).

\section{Measurement}

\section{Commercial vs. Subsistence Orientation}

Commercial/subsistence orientation of the farmers was identified based on the revealed response of their intended main purpose of cultivating each type of crop. Cultivating crops for selling in the market was considered as commercial orientation and cultivating crops in order to fulfill their consumption requirements was taken as subsistence orientation.

\section{Market vs. Production Orientation}

The degree of market or production orientation shown by farmers was assessed based on the number of market or production orientated decision criteria adopted by each respondent (See Table 2). In this context, the routine decision criteria devoid of market considerations were considered as production orientated factors and the corresponding decisions deviated from routine production orientated practices with the intentions of capitalizing market opportunities (i.e. to obtain higher farm gate prices) were considered as market orientated factors. Altogether 6 decision criteria were identified for each orientation ${ }^{5}$ (See Table 2). In assessing the market or production orientation shown by farmers one mark was assigned for each decision criteria

5 The scale was decided based on the most common decision criteria (altogether six criteria under which more than one market/production oriented practices may prevail) adopted by each farmer in his/her production/ marketing decision making process which were identified as an outcome of the initial round of data analysis. 
adopted by each farmer. Hence the total attainable score by a farmer for each orientation per given crop (i.e. paddy, OFC and vegetables) varied from zero to six. The total score earned by a farmer for each orientation hence was taken as indication of his/her degree of market and/or production orientation, which was assessed separately for each type of crop grown.

Table 2: Decision Criteria Used for Assessing the Degree of Production/Market Orientation

\begin{tabular}{|c|c|c|}
\hline $\begin{array}{l}\text { Decision } \\
\text { criteria }\end{array}$ & Market oriented practices & $\begin{array}{l}\text { Production oriented } \\
\text { practices }\end{array}$ \\
\hline \multirow[t]{7}{*}{$\begin{array}{l}\text { 1. Type of } \\
\text { crop }\end{array}$} & $\begin{array}{l}\text { to take advantage of market } \\
\text { windows (i.e. high market } \\
\text { price) }\end{array}$ & $\begin{array}{l}\text { as a part of routine practices } \\
\text { adopted by other farmers in } \\
\text { the area }\end{array}$ \\
\hline & $\begin{array}{l}\text { as a result of a buyback } \\
\text { contract relationship }\end{array}$ & $\begin{array}{l}\text { in order to match with the } \\
\text { prevailing agro ecological } \\
\text { factors }\end{array}$ \\
\hline & & $\begin{array}{l}\text { based on advice received } \\
\text { from NGOs/extension services } \\
\text { etc. }\end{array}$ \\
\hline & & $\begin{array}{l}\text { due to availability of planting } \\
\text { material free of charge from } \\
\text { external sources }\end{array}$ \\
\hline & & $\begin{array}{l}\text { due to possession of technical } \\
\text { knowledge }\end{array}$ \\
\hline & & $\begin{array}{l}\text { as a result of the highest } \\
\text { priority given } \\
\text { availability/ownership of } \\
\text { resources (i.e. } \\
\text { land/labour/capital) }\end{array}$ \\
\hline & & $\begin{array}{l}\text { in order to meet consumption } \\
\text { needs }\end{array}$ \\
\hline \multirow[t]{3}{*}{$\begin{array}{l}\text { 2. Time of } \\
\text { cultivation }\end{array}$} & \multirow[t]{3}{*}{$\begin{array}{l}\text { to take advantage of market } \\
\text { windows (i.e. high market } \\
\text { prices) }\end{array}$} & $\begin{array}{l}\text { as a part of routine practices } \\
\text { adopted by other farmers in } \\
\text { the area (as others in the area } \\
\text { are cultivating at the same } \\
\text { time) }\end{array}$ \\
\hline & & due to availability of water \\
\hline & & due to availability of labour \\
\hline
\end{tabular}




\begin{tabular}{|c|c|c|}
\hline $\begin{array}{l}\text { Decision } \\
\text { criteria }\end{array}$ & Market oriented practices & $\begin{array}{l}\text { Production oriented } \\
\text { practices }\end{array}$ \\
\hline \multirow{3}{*}{$\begin{array}{l}\text { 3.Place/buyer } \\
\text { to sell }\end{array}$} & to obtain price advantages & \multirow{3}{*}{$\begin{array}{l}\text { sold to a specific place/person } \\
\text { as there is no freedom of } \\
\text { choice due to presence of } \\
\text { credit bound relationships }\end{array}$} \\
\hline & $\begin{array}{l}\text { due to trust based market } \\
\text { linkages }\end{array}$ & \\
\hline & $\begin{array}{l}\text { due to attached service } \\
\text { package }\end{array}$ & \\
\hline \multirow[t]{2}{*}{$\begin{array}{l}\text { 4. Time of } \\
\text { selling }\end{array}$} & \multirow{2}{*}{$\begin{array}{l}\text { to take advantage of time } \\
\text { based market windows (i.e. } \\
\text { to avoid market gluts) }\end{array}$} & $\begin{array}{l}\text { as a part of routine practices } \\
\text { by other farmers in the area }\end{array}$ \\
\hline & & $\begin{array}{l}\text { sold just after harvesting as } \\
\text { there are no other choices due } \\
\text { to credit burdens (also as a } \\
\text { result of credit bound } \\
\text { relationships) }\end{array}$ \\
\hline $\begin{array}{l}\text { 5.Form of } \\
\text { selling }\end{array}$ & $\begin{array}{l}\text { to get higher profit/price } \\
\text { advantage }\end{array}$ & due to lack of storage facilities \\
\hline $\begin{array}{l}\text { 6.Grading } \\
\text { and selling }\end{array}$ & $\begin{array}{l}\text { graded and sold at different } \\
\text { qualities for different } \\
\text { prices }\end{array}$ & $\begin{array}{l}\text { sold without grading as a part } \\
\text { of routine practices by other } \\
\text { farmers }\end{array}$ \\
\hline
\end{tabular}

\section{Data Analysis}

Data was analyzed descriptively and Chi-square goodness-of-fit test was carried out to test whether there is a significant difference in subsistence vs. commercial orientation of farmers with respect to different crops cultivated. In comparing the degree of market/production orientation of farmers, the mean scores were calculated with respect to market and production oriented decision criteria adopted with respect to different crops.

\section{Results and Discussion}

The paper first describes the socio-economic profile of the respondents as the findings should be interpreted in relation to their demographic and economic profiles. However, the high homogeneity observed in terms of education, ethnicity and economic status restricted identification of patterns and relationships. 


\section{Description of the Sample}

The majority of households belonged to the monthly income category of less than Rs. 5000 (See Table 1). The Average weekly expenditure on food Items is Rs.1250. The Colombo Consumer Price Index (CCPI) value of the Official Poverty Line (OPL) for 2006 is Rs. 2233 real total expenditure per month per person. According to census and statistics (2006) $15.2 \%$ of the population lives below this line. Since the average family size of the sample was four, it is obvious that majority of the households in the sample of the study live below the OPL.

\begin{tabular}{cc}
\hline $\begin{array}{c}\text { Income Category } \\
\text { Rs./month }\end{array}$ & Percentage of Farmers \\
\hline $0-5,000$ & 55.7 \\
$5,001-10,000$ & 21.9 \\
$10,001-15,000$ & 14.8 \\
$15,001-20,000$ & 5.9 \\
$>20,000$ & 1.7 \\
\hline
\end{tabular}

The average land extent of the farms were 1.7 Ac of lowland, 1.9 Ac of upland and 1.5 Ac of homegarden. In the agricultural smallholding sector, majority of the holdings belong to the land extent of 1-2 Acres (Department of Census and Statistics, 2002). This also implies that these farmers are small holders.

\section{Subsistence vs. Commercial Orientation}

Of the respondents, $78 \%$ of the farmers cultivate paddy, OFCs and vegetables. The majority of them found to be cultivating paddy and vegetables mainly for subsistence purpose i.e. to fulfill consumption requirements. The subsistence orientation was predominant in the case of vegetables, followed by paddy (See Table 3 ). This was also made evident by the fact that vegetable cultivation was carried out by farmers at miniscule levels in their home gardens. In contrast, OFCs (Other Field Crops) were mainly cultivated for commercial purposes (See Table 3). Chi-square analysis carried out to test whether subsistence and commercial orientations demonstrated by farmers differ in relation to the type of crop cultivated revealed that there is a significant difference $(\chi 2=114.169,0.05)$ in relation to paddy, OFCs and vegetables. On the other hand it was impossible to classify a 
given crop as purely subsistence oriented as the surplus is sold. Overall findings indicated that the respondents cannot discreetly be divided into subsistence and commercial farmers as such orientation varied with the type of crop cultivated and not with the individual farmers.

\begin{tabular}{lccc} 
Table 3: & Purpose of Crop Cultivation as Perceived by Respondents \\
\hline Purpose & $\begin{array}{c}\text { Paddy } \\
\mathbf{\%}\end{array}$ & $\begin{array}{c}\text { OFCs } \\
\mathbf{\%}\end{array}$ & $\begin{array}{c}\text { Vegetables } \\
\mathbf{\%}\end{array}$ \\
\hline Subsistence & 56.18 & 39.07 & 68.06 \\
Commercial & 43.82 & 60.93 & 31.94 \\
\hline
\end{tabular}

\section{Production vs. Market Orientation}

As far as the business orientation of the farmers in terms of their production and market orientation is concerned, the findings tend to closely follow the pattern they demonstrated with respect to commercial and subsistence orientation (i.e. associated with the type of crop cultivated) with the highest degree of production orientation shown in relation to paddy followed by vegetables and OFCs. The farmers were only slightly inclined towards market orientation with respect to OFCs. This finding closely associated with the highest commercial orientation shown by farmers towards OFCs as well. Although the cultivation of vegetables was associated with the highest subsistence orientation, paddy was found to be the crop grown with the highest production orientation (See Table 4).

Table 4: $\quad$ Mean Values obtained for Production/Marketing Orientation in Relation to Paddy, OFCs and Vegetables

\begin{tabular}{lccc}
\hline Orientation & $\begin{array}{c}\text { Paddy } \\
\text { Mean Value }\end{array}$ & $\begin{array}{c}\text { OFCs } \\
\text { Mean Value }\end{array}$ & $\begin{array}{c}\text { Vegetables } \\
\text { Mean Value }\end{array}$ \\
\hline Production & $3.70(S D=1.00)$ & $2.51(S D=.91)$ & $3.58(S D=.76)$ \\
Marketing & $0.84(S D=.96)$ & $0.92(S D=.87)$. & $0.58(S D=.85)$. \\
\hline
\end{tabular}

Figures 1 graphically depicts the number of production and market oriented decision criteria considered by the respondents in relation to each crop, i.e. paddy, OFCs and vegetables respectively. Findings reveal that farmers considered only a very limited number of market orientated factors 
(around 1 to 3 ) as opposed a higher number of production orientated factors considered by them. This further demonstrates the farmers' greater inclination towards the production orientation, immaterial of the type of crop cultivated.

Figure 1: $\quad$ Number of Market/Production Oriented Aspects Considered in Relation to Paddy, OFCs and Vegetables

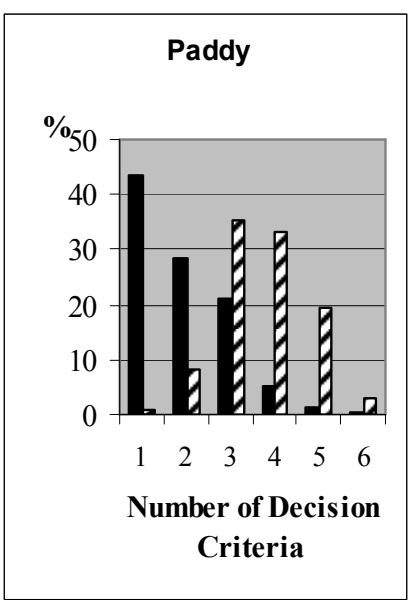

Market oriented aspects
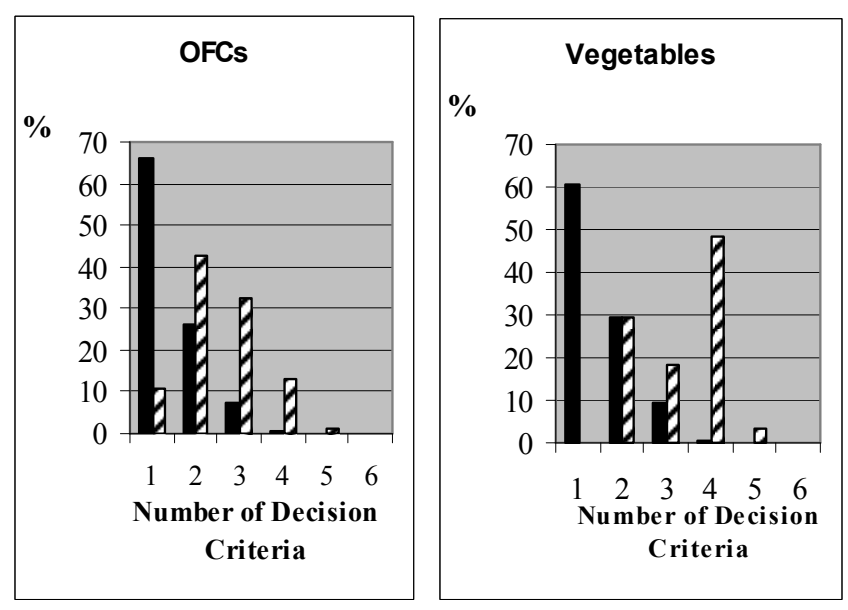

Production oriented aspects

The most predominantly considered market oriented aspect was the differentiation of the selling options (i.e. where to sell), which was adopted mainly in order to take the price advantage in the case of all the types of crops considered (See Figure 2). Proactive decisions taken in terms of the selection of the crop variety (i.e. what to produce) for cultivation purpose in order to get a higher market price was mainly visible in relation to OFCs and vegetables with little consideration given to differentiation of paddy cultivation in terms of varieties grown (i.e. Samba vs. Nadu etc.). This further proved the higher inclination of production orientation shown by farmers towards the paddy crop. The second most common market oriented decision taken by the farmers in relation to paddy was found to be deciding on a specific time of selling to take advantage of higher market prices whereas for $\mathrm{OFC}$ it was found to be differentiation of the varieties of OFCs grown (i.e. what to produce). In the case of paddy, changing the time of selling (i.e. when to sell- store and sell) is found to be one of the most commonly adopted marketing oriented strategies by paddy farmers. This has also been found by 
Kodithuwakku (1997). This practice has been facilitated by the less perishable nature of paddy compared to other types of crops grown. Findings also revealed that value addition to paddy (i.e. changing the form of selling, through processing) was not a common practice among the respondents,

Figure 2: Market Oriented Factors Considered by Farmers by Crop Type

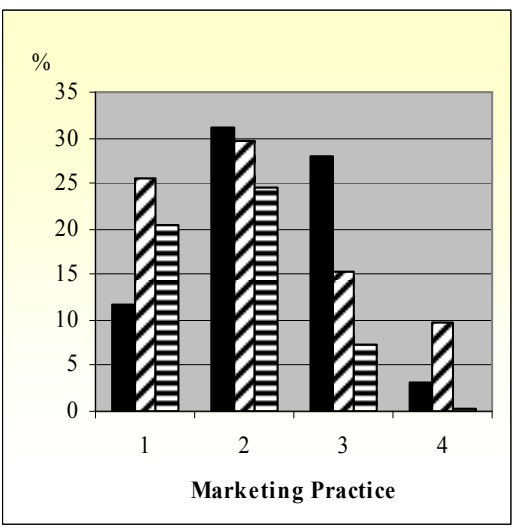

Paddy

$\square$ OFC

目 Vegetables

\section{Market oriented practices}

1 Type of crop is decided to take advantage of high market price

2 Sold to a specific place/person to obtain price advantages

3 Deciding on specific time of selling to take advantage of high market price

4 Form is decided to get higher profit/price advantage
Figure 3: Production Oriented

Factors Considered

Farmers by Crop Type

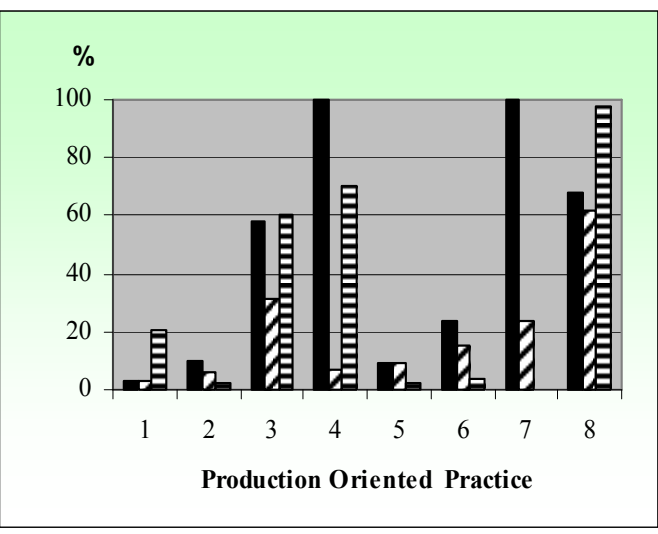

Production oriented practices

1 Type of crop is decided due to availability of planting material free of charge from external sources

2 Type of crop is decided due to possession of technical knowledge 3Type of crop is decided in order to meet consumption needs

4 Time of cultivation is decided due to availability of water

5Sold to a specific place/person as there is no freedom of choice due to credit bound relationships

6 Specific time selling is decided as there are no other choices due to credit bound relationships

7 Form of selling is decided due to lack of storage facilities

8 Sold without grading as a part of routine practices by other farmers 
though the said aspect was visible relatively at a higher degree in the case of OFC, which usually found to be adopted at a very low scale in terms of sundrying of crops. However, it was found that the farmers have given little or no attention for deciding on a specific time of cultivation to capture market windows and grading and selling crops in different qualities to obtain price advantage. The lack of grading of crops by farmers could however, be attributed to the nature of the prevailing supply chains for agricultural products as been explained by Perera et al., (2004) which usually does not facilitate price and quality signals passing down to the farm gate levels.

It was interesting to find out that not only production orientation but also market orientation revolved around few routinely made marketing related decisions, with the least degree of differentiation among farmers. This can be taken as a lucid example of the tendency of poor farmers to be engaged in routine practices, be it production or marketing which as has been argued by Bryant (1989), is usually caused by the increased openness of the production environment.

As far as the specific production orientated practices adopted by the farmers are concerned, it was evident that farmers have taken into consideration a higher number of production orientated practices, as opposed to a lesser number of market oriented practices in their portfolio of production decision making. It was also evident that the type of such practices adopted varied with the type of crop cultivated. In the case of paddy, the mot predominantly attended aspects were found to be deciding of a specific time of cultivation in order to match with water availability and selling of paddy just after harvesting due to lack of storage facilities. Presence of subsistence orientation as well as lack of quality differentiation at the point of selling were also found to be associated with paddy, although the percentages of farmers who adopted such practices in relation to vegetables were found to be relatively higher (see Figure 3). Most predominately adopted production oriented practice in relation to vegetables was found to be disposing them to the market without any quality differentiation followed by the decisions taken on the time of cultivation to match with the water availability and consumption orientation with regard to the selection of crops to be grown. The main routine production oriented practice adopted by farmers in relation to the $\mathrm{OFC}$ was found to be not going for quality differentiation at the time of selling to get price advantages. This was followed by consumption orientation in the crop selection. 


\section{Conclusions and Policy Implications}

This study attempted to investigate the business orientation of farmers in terms of subsistence versus commercial and production versus market orientation of the dry zone farmers. Farmers could not discreetly be divided into subsistence or commercial groups as such orientations varied with the type of crops cultivated and not with the individual farmer. It was also impossible to classify a given crop as purely subsistence focused as the surplus was sold. As far as the business orientation of the farmers in terms of their production and market orientation is concerned, the farmers showed a greater inclination towards production orientation, irrespective of the crops grown, with a slightly higher market orientation shown with respect to OFCs. Overall findings indicated that farmers had considered only a very limited number of market orientated criteria (around 1 to 3) as opposed to a higher number of production orientated criteria considered by them. It was interesting to find out that the narrow market orientation exhibited also revolved around few routinely made marketing related decisions, with the least degree of differentiation among farmers. This can be taken as a good example of the tendency of poor farmers to engage in routine practices, be it production or marketing, which is usually caused by the increased openness of the production environment. These findings raise major policy implications for rural development as majority of rural inhabitants are directly or indirectly dependant upon agriculture as their main livelihood activity. If a meaningful solution to rural poverty be given, it is essential that the mind set of the rural farming community is changed from production to market orientation, without which efforts taken to up-scale rural communities would not be realized efficiently and effectively. Tailor made training and development programmes coupled with linking farmers with the market through forward/buy back contact agreements would be proposed as appropriate strategies as such linkages would enable the farmers to respond to price and quality signals. The exorbitant growth of food retail chains in the country could be cited as a great opportunity for achieving this objective.

\section{Suggestions for Future Research}

Studies carried out with a more heterogeneous sample of farmers would enable to identify patterns and relationships findings of which would be more beneficial in policy implementation. 


\section{Acknowledgements}

Authors wish to acknowledge the World Vision Lanka for facilitating the access to the beneficiaries of USDA/WVL IFSA project for data collection.

\section{References}

Barkley, D. L., and P. N. Wilson (1992). Is Alternative Agriculture a Viable Rural Development Strategy? Growth and Change, Vol. 23 (Spring).

Brunaker, S. (1990). Formulating, Evaluating and Choosing Strategies for Farm Diversification. In, J. Christensen, S. Rasmussen, P. E. Stryg and Pedersen, D. E (eds.). Managing Long Term Developments of the Farm Firm: Strategic Planning and Management. Proceedings of the 23rd Symposium of the European Association.

Bryant, C.R. (1989). Entrepreneurs in the Rural Environment. Journal of Rural Studies, 5(4).

Carkner, R.W. (1989). Choosing Enterprise for Your Farm. Farm Management: How to Achieve Your Farm Business Goals, Year Book of Agriculture. USDA.

Colette, W. A., and G. B. Wall (1978). Evaluating Vegetable Production for Market Windows as an Alternative for Limited Resource Farmers. Southern Journal of Agricultural Economics, Vol.10.

Cornelius, J.C. (1988). How to Develop a Successful Market Strategy. Marketing US Agriculture: Year Book. USDA.

Dagher, M.A., and R. D. Christy (1991). Limited Resource Farmers and the Marketing System. American Journal of Agricultural Economics, December.

Department of Census and Statistics, (2002). Census of Agriculture. Department of Census and Statistics, Sri Lanka. 
Department of Census and Statistics, (2006). Household Consumption and Expenditure Survey, Department of Census and Statistics, Sri Lanka.

Ferris, J.N. (1988). Marketing Strategies and Alternatives for Individual Farmers. Marketing US Agriculture: Year Book. USDA.

Giles, A.K. (1990). Managers and the Economic Environment. In, T. Giles (ed.). The Manager's Environment. Centre of Management in Agriculture, University of Reading.

Gutierrez, P.H. and N.L. Dalsted (1989). Integrating Production and Marketing Management on a Beef Ranch. Farm Management: How to Achieve Your Farm Business Goals, Year Book of Agriculture. USDA.

Ikerd, J.E. (1989). Determining Your Competitive Advantage. Farm Management: How to Achieve Your Farm Business Goals, Year Book of Agriculture. USDA.

Janssens, S.R.M. and J. Krikke (1990). Business Planning for Arable Farming and Field Production of Vegetables. In, J. Christensen, S. Rasmussen, P.E. Stryg and D.E. Pedersen (eds.). Managing Long Term Developments of the Farm Firm: Strategic Planning and Management, Proceedings of the 23rd Symposium of the European Association of Agricultural Economists (Nov, 1988). Copenhagen, Denmark.

Johnston, T.R.R. and C.R. Bryant (1987). Agricultural Adaptation: The Prospects of Sustaining Agriculture near Cities. In, W. Lockerretz (ed.). Sustaining Agriculture Near Cities. Soil and Water Conservation Society. Iowa.

King, R.P. and S.T. Sonka (1985). Management Problems of Farms and Agricultural Firms. Discussion Paper No. 44. Strategic Management Research Center, University of Minnesota.

Kodithuwakku, S. (1996). Demonstration Case Study: Indigenous Entrepreneurship in Sri Lankan Rice Farmers. In, P. Rosa, M.G. 
48

Scott, and H. Klandt (eds.). Educating Entrepreneurs in Modernising Economies, Stirling Management Series, Avebury: Hants.

Kodithuwakku, K.A.S.S. (1997). Entrepreneurial Processes in an Apparently Uniform Context: A Study of Rural Farmers in Sri Lanka. Unpublished $\mathrm{PhD}$ Thesis, Department of Organization and Management, University of Stirling, UK.

Kodithuwakku, S.S. and P. Rosa (2002). The Entrepreneurial Success in a Constrained Environment. Journal of Business Venturing, (Special Issue on Qualitative Research in Entrepreneurship), 17:(5) August 431-465.

Meulenberg, M.T.G. (1986). The Evolution of Agricultural Marketing Theory: Towards better Coordination with General Marketing Theory. Netherlands Journal of Agricultural Science, Vol. 34.

Nelson, A.G. (1989). How Farm Managers Make Risky Decisions? Farm Management: How to Achieve Your Farm Business Goals. Year Book of Agriculture. USDA.

Perera, M., S.S. Kodithuwakku and J. Weerahewa (2004) Analysis of Vegetable Supply Chains of Supermarkets in Sri Lanka. Sri Lankan Journal of Agricultural Economics, 6(1): 67-81.

Smidts, A. (1990). Decision Making Under Risk: A Study of Models and Measurement Procedures with Special Reference to Farmers' Marketing Behaviour (based on $\mathrm{PhD}$ thesis). Wageningse Economische Studies.

Silva, K.T., S.B.D. de Silva, S.S. Kodithuwakku, M.G.M. Razak, J. Ananda, I.M. Gunawardena and D. Lux (1999). No Future in Farming? The Potential Impact of Commercialization of Non-Plantation Agriculture on Rural Poverty in Sri Lanka, Kandy: Centre for Inter-Sectoral Community and Health Studies (CICHS)/GTZ.

White, G.B. (1989). Using Strategic Planning to Prepare for the Future. Farm Management: How to Achieve Your Farm Business Goals, Year Book of Agriculture. USDA. 
Wossink, G.A.A. (1990). The Significance of a Farm Economic Approach to Analyse the Effects of Technical Change in Agriculture. In, J. Christensen, S. Rasmussen, P.E. Stryg and D.E. Pedersen (eds.). Managing Long Term Developments of the Farm Firm: Strategic Planning and Management. Proceedings of the 23rd Symposium of the European Association of Agricultural Economists (Nov, 1988). Copenhagen, Denmark. 